\title{
Increasing the Addition of Two Total Numbers Learning Results Through The Problem Based Learning (PBL) Model Assisted By Visual Audio Media In SD Students
}

\section{Sri Wilujeng}

SDN 02 Banjarsari

jeng90pemalang@gmail.com

\section{Article History}

accepted 14/11/2020

\begin{abstract}
The purpose of Classroom Action Research (CAR) is to solve real problems that occur in the classroom so that it can improve and improve the quality of learning. This PTK generally aims to improve the learning outcomes of grade III students in mathematics subject matter at SD Negeri 02 Banjarsari Pemalang. To achieve optimal results, teachers need to use a learning model that can help students relate subject matter to real life, so that learning becomes more meaningful. This model is the Problem Based Learning (PBL) model. The results showed an increase in student learning outcomes from cycle I to cycle II. In the first cycle, the average value of student learning outcomes reached 77.78 and the percentage of completing classical learning was $77.78 \%$, while in the second cycle the average value increased to 84.44 and the percentage of completing classical learning became $88.89 \%$. Based on these results, it can be concluded that the PBL model assisted by audio-visual media can improve student learning outcomes. Teachers can use the PBL model as an alternative learning model to improve the quality of learning in schools.
\end{abstract}

Keywords: learning outcomes, problem based learning ( $P B L)$ model, audio visual media

\begin{abstract}
Abstrak
Tujuan Penelitian Tindakan Kelas (PTK) yaitu untuk memecahkan permasalahan nyata yang terjadi di dalam kelas sehingga dapat memperbaiki dan meningkatkan kualitas pembelajaran. PTK ini secara umum bertujuan untuk meningkatkan hasil belajar siswa kelas III pada muatan pelajaran matematika di SD Negeri 02 Banjarsari Pemalang. Untuk mencapai hasil yang optimal, guru perlu menggunakan model pembelajaran yang dapat membantu siswa mengaitkan materi pelajaran dengan kehidupan nyata, sehingga pembelajaran menjadi lebih bermakna. Model tersebut yaitu model Problem Based Learning (PBL). Hasil penelitian menunjukkan adanya peningkatan hasil belajar siswa dari siklus I ke siklus II. Pada siklus I, nilai rata-rata hasil belajar siswa mencapai 77,78 dan persentase tuntas belajar klasikal $77,78 \%$, sedangkan pada siklus II nilai rata-rata meningkat menjadi 84,44 dan persentase tuntas belajar klasikal menjadi $88,89 \%$. Berdasarkan hasil tersebut, dapat disimpulkan model PBL berbantuan media audio visual dapat meningkatkan hasil belajar siswa. Guru dapat menggunakan model PBL sebagai alternatif model pembelajaran untuk meningkatkan kualitas pembelajaran di sekolah.
\end{abstract}

Kata kunci : hasil belajar, model problem based learning (PBL), media audio visual

Social, Humanities, and Education Studies (SHEs): Conference Series https://jurnal.uns.ac.id/shes

p-ISSN 2620-9284 e-ISSN 2620-9292 


\section{PENDAHULUAN}

Dalam tujuan kurikulum 2013, siswa dituntut untuk berpikir lebih kreatif, inovatif, cepat dan tanggap dan selain itu dalam kurikulum 2013 siswa dilatih untuk menumbuhkan keberanian dalam dirinya. Siswa akan dilatih kemampuan berlogika dalam memecahkan suatu permasalahan. Namun dalam kenyataannya, proses pembelajaran yang dilakukan guru di sekolah dasar pada umumnya masih belum berjalan secara maksimal. Terlebih lagi dalam kondisi pandemi covid seperti sekarang ini, guru dalam proses pembelajaran masih sering menggunakan metode membagikan buku elektronik untuk menyampaikan materi, sedangkan materi dalam matematika adalah konsep yang bersifat abstrak. Proses pembelajaran masih berpusat pada guru (teacher centered). Akibatnya, matematika dianggap sebagai salah satu mata pelajaran di SD yang sulit dan capaian hasil belajar siswa kurang maksimal. Keadaan yang demikian juga terjadi dalam muatan pelajaran Matematika di kelas III SD Negeri 02 Banjarsari, khususnya materi penjumlahan dua bilangan cacah.

Berdasarkan refleksi pembelajaran yang telah dilaksanakan, masih ada siswa yang memperoleh hasil belajar matematika materi penjumlahan dua bilangan cacah di bawah Kriteria Ketuntasan Minimal (KKM) yaitu 68. Guru kurang maksimal dalam menggunakan media pembelajaran. Siswa kurang diberi kesempatan untuk menyusun pegetahuannya sendiri dalam proses belajarnya. Keadaan yang demikian juga membuat siswa berpikir bahwa apa yang mereka pelajari tidak bermakna bagi kehidupannya kelak, sehingga siswa tidak ada motivasi untuk belajar matematika. Beberapa teori belajar dalam pembelajaran matematika yang relevan dengan penelitian ini yaitu teori belajar Piaget, Brunner, dan Vygotsky.

Teori belajar Piaget memberikan landasan bahwa siswa SD berada pada tahap operasional konkret, sehingga guru dalam membantu siswa memahami materi penjumlahan dan pengurangan pecahan membutuhkan benda-benda atau situasi yang konkret. Menurut Piaget dalam Rifa'i dan Catharina (2009: 26-30), tahap-tahap perkembangan kognitif siswa mencakup tahap sensorimotorik, pra-operasional, operasional konkret, dan operasional formal. Teori belajar Brunner memberikan landasan bahwa dalam menyajikan materi penjumlahan dan pengurangan pecahan dimulai dengan memberikan pengalaman konkret melalui kegiatan memanipulasi objek-objek konkret. Pada tahap berikutnya siswa dapat belajar memahami materi penjumlahan dan pengurangan pecahan melalui gambaran dari objek nyata. Kemudian siswa dapat memahami simbol-simbol secara langsung. Menurut Brunner dalam Pitajeng (2006: 29), anak-anak berkembang melalui tiga tahap perkembangan mental yaitu tahap enaktif, ikonik, dan simbolik. Teori Vygotsky berusaha mengembangkan model konstruktivistik belajar mandiri dari Piaget menjadi belajar kelompok. Menurut Vygotsky dalam Muhsetyo dkk (2009: 1.11), dalam membangun pengetahuannya sendiri, siswa dapat memperoleh pengetahuan melalui kegiatan yang beranekaragam dengan guru sebagai fasilitator. Kegiatan itu dapat berupa diskusi kelompok kecil, diskusi kelas, dan mengerjakan tugas kelompok.

Rumusan masalah dalam penelitian ini memfokuskan pada peningkatan hasil belajar siswa, yaitu (1) Apakah penerapan model PBL berbantuan media audio visual dapat meningkatkan hasil belajar penjumlahan dua bilangan cacah pada kelas III SD Negeri 02 Banjarsari Pemalang? (2) Bagaimana meningkatkan hasil belajar siswa kelas III SD Negeri 02 Banjarsari Pemalang pada materi penjumlahan dua bilangan cacah melalui model PBL berbantuan media audio visual?. Tujuan penelitian merupakan tujuan yang ingin dicapai oleh peneliti dengan mendasarkan pada permasalahan yang dikemukakan. Tujuan utama PTK yaitu untuk memecahkan permasalahan nyata yang terjadi di dalam kelas sehingga dapat memperbaiki dan meningkatkan kualitas pembelajaran. Tujuan Pelaksanaan PTK ini secara umum bertujuan untuk meningkatkan hasil belajar siswa kelas III pada muatan pelajaran matematika di SD Negeri 02 Banjarsari Pemalang. 


\section{METODE}

Penelitian Tindakan Kelas adalah penelitian praktis yang dimaksudkan untuk memperbaiki pembelajaran di kelas. Penelitian ini merupakan upaya guru untuk memperbaiki dan meningkatkan mutu pembelajaran di kelas. Menurut Arikunto, Suhardjono, dan Supardi (2008: 16) penelitian ini dilaksanakan dengan rancangan PTK yang terdiri dari empat tahap yaitu (1) perencanaan, (2) pelaksanaan tindakan, (3) pengamatan (observasi), dan (4) refleksi. Penelitian ini dilaksanakan di SD Negeri 02 Banjarsari Pemalang yang beralamat di Jalan H.Hasyim No.38 Kecamatan Bantarbolang Kabupaten Pemalang. Waktu penelitian pada Semester 1 Tahun Pelajaran 2020/2021. Subjek dalam penelitian tindakan kelas ini adalah siswa kelas III yang berjumlah 9 siswa. Untuk mengumpulkan data, diperlukan teknik pengumpulan data yang dilakukan dengan teknik tes. Menurut Riduwan (2010: 98), instrumen atau alat pengumpul data merupakan alat bantu yang dipilih dan digunakan oleh peneliti dalam kegiatannya mengumpulkan data agar kegiatan tersebut menjadi sistematis dan dipermudah olehnya. Alat pengumpul data yang digunakan dalam penelitian ini yaitu alat tes. Setelah data terkumpul, peneliti melakukan analisis data untuk memperoleh hasil penelitian yang telah dilaksanakan. Teknik analisis data yang digunakan yaitu analisis data hasil belajar siswa. Rumus-rumus yang digunakan untuk menganalisis data hasil belajar siswa yaitu nilai akhir hasil belajar siswa dalam BSNP (2007: 25), nilai rata-rata kelas dalam Sudjana (2010: 109), dan persentase tuntas belajar klasikal dalam Aqib dkk (2010: 41).

\section{HASIL DAN PEMBAHASAN}

Hasil penelitian yang telah dilakukan adalah sebagai berikut:

\section{Deskripsi Data Pelaksanaan Siklus I}

Deskripsi data pelaksanaan siklus I terdiri data hasil belajar selama proses pembelajaran.

\section{a. Paparan Hasil Belajar}

Hasil belajar ditunjukkan dengan nilai yang diperoleh siswa setelah menempuh tes formatif. Berikut ringkasan hasil belajar siswa sesudah pembelajaran:

Tabel 1. Data Hasil Tes Formatif Siklus I

\begin{tabular}{|l|l|l|}
\hline Skor(x) & $\mathbf{F}$ & Fx \\
\hline 100 & 1 & 100 \\
\hline 95 & - & 0 \\
\hline 90 & 2 & 180 \\
\hline 85 & - & 0 \\
\hline 80 & 2 & 160 \\
\hline 75 & - & - \\
\hline 70 & 2 & 140 \\
\hline 65 & - & - \\
\hline 60 & 2 & $\mathbf{7 0 0}$ \\
\hline Jumlah & 9 & $=\frac{700}{9}$ \\
Nilai rata-rata kelas & $=77,78$ \\
TBK & $=\frac{N \text { (nilai } 68 \text { ) }}{S N} \times 100 \%$ \\
& $=\frac{7}{9}$ X $100 \%=77,78 \%$ \\
\end{tabular}


Berdasarkan hasil tabel di atas diketahui bahwa nilai rata-rata kelas pada siklus I adalah 77,78. Sedangkan ketuntasan belajar secara klasikal 77,78\% dan yang belum tuntas $22,22 \%$. Hasil tersebut di atas dapat digambarkan dalam diagram berikut:

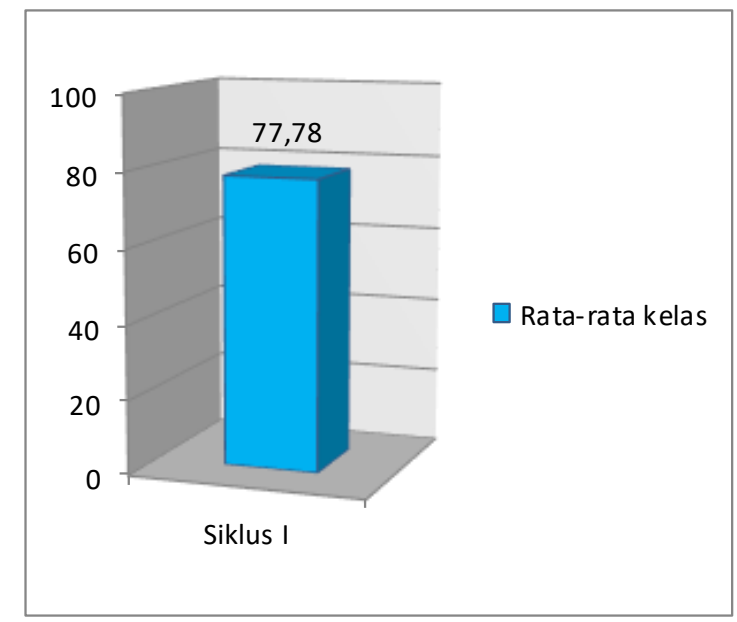

Diagram 1. Rata-rata kelas siklus I

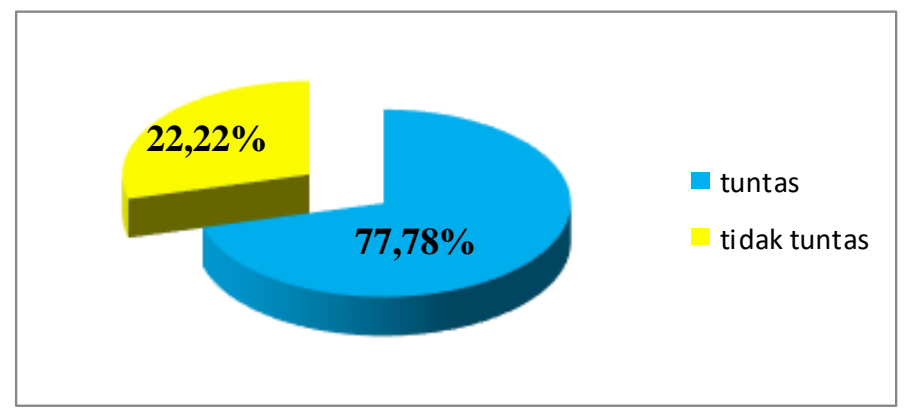

Diagram 2. Ketuntasan belajar siswa secara klasikal siklus I

\section{b. Refleksi}

Refleksi setelah melaksanakan siklus I adalah masih banyak kekurangan dalam menerapkan model pembelajaran Problem Based Learning (PBL) dan terdapat kekurangan guru saat mengelola kelas. Hal ini dapat dibuktikan dari hasil evaluasi siswa.

Hasil belajar pada siklus I yaitu pada tes formatif menunjukkan nilai rata-rata kelas sebesar 77,78 dan persentase ketuntasan belajar mencapai $77,78 \%$. Pada hasil tes masih terdapat 2 siswa yang mendapatkan nilai dibawah kriteria yang ditentukan yaitun 68 .

Selain hasil tes, terdapat juga beberapa kekurangan saat melakukan kegiatan pembelajaran dengan menggunakan model PBL. Kekurangan tersebut dapat dibuktikan dari dalam pembuatan RPP, guru kurang dapat mengembangkan media pembelajarn yang dapat menarik perhatian siswa sehingga materi yang diajarkan akan mudah diterima siswa. 


\section{c. Revisi}

Berdasarkan hasil refleksi di atas, maka hasil yang belum mencapai indikator keberhasilan tersebut akan diperbaiki dan ditingkatkan pada siklus II. Perbaikan yang akan dilakukan pada siklus II adalah peningkatan hasil belajar dan penggunaan media audio visual agar pembelajaran lebih menarik dan siswa lebih menguasai materi pembelajaran.

\section{Deskripsi Data Pelaksanaan Siklus II}

Pada siklus II pelaksanaan pembelajaran dilakukan berdasarkan refleksi pada siklus I. Peneliti melakukan pembelajaran pada siklus II dengan penggunaaan media pembelajaran yang menarik. Hasil dari pelaksanaan siklus II adalah sebagai berikut:

\section{a. Paparan Hasil Belajar}

Tes hasil belajar siklus II ini dilaksanakan pada akhir pembelajaran. Data tes hasil belajar siswa siklus II, dapat dilihat pada tabel berikut ini.

\begin{tabular}{lll}
\multicolumn{2}{c}{ Tabel 2. Data Tes Hasil Belajar Siswa Siklus II } \\
\hline Skor (x) & $\mathbf{f}$ & Fx \\
\hline 100 & 2 & 200 \\
95 & - & 0 \\
90 & 3 & 270 \\
85 & - & - \\
80 & 2 & 160 \\
75 & - & - \\
70 & 1 & 70 \\
65 & - & - \\
60 & 1 & 60 \\
$0-55$ & - & - \\
Jumlah & 9 & 760 \\
\hline
\end{tabular}

$$
\begin{aligned}
& \text { Nilai rata-rata kelas }=\frac{760}{9} \\
& =84,44 \\
& \text { TBK }=\frac{N \text { (nilai }>68)}{S N} \times 100 \% \\
& =\frac{8}{9} \times 100 \% \\
& =88,89 \%
\end{aligned}
$$

Berdasarkan hasil tabel di atas diketahui bahwa nilai rata-rata kelas pada siklus II adalah 84,44. Sedangkan ketuntasan belajar secara klasikal 88,89\% dan yang tidak tuntas $11,11 \%$. Hasil tersebut di atas dapat digambarkan dalam diagram sebagai berikut: 


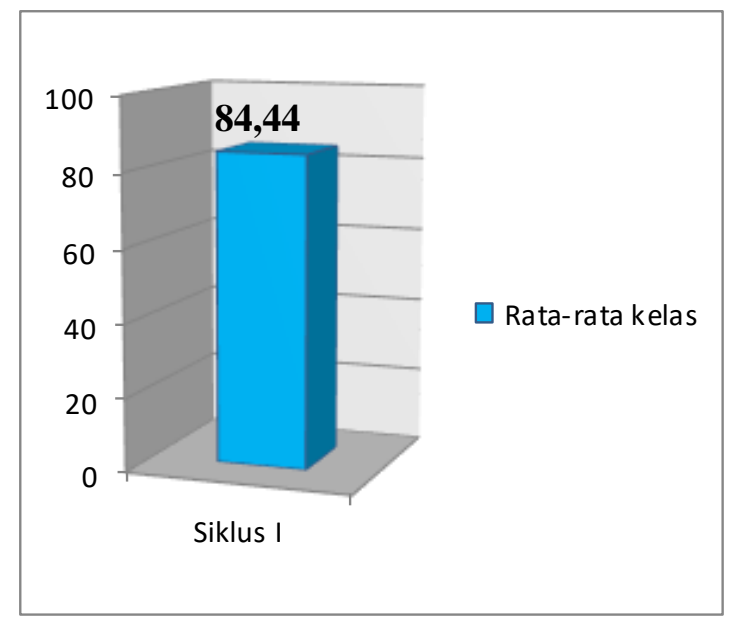

Diagram 3. Rata-rata kelas siklus II

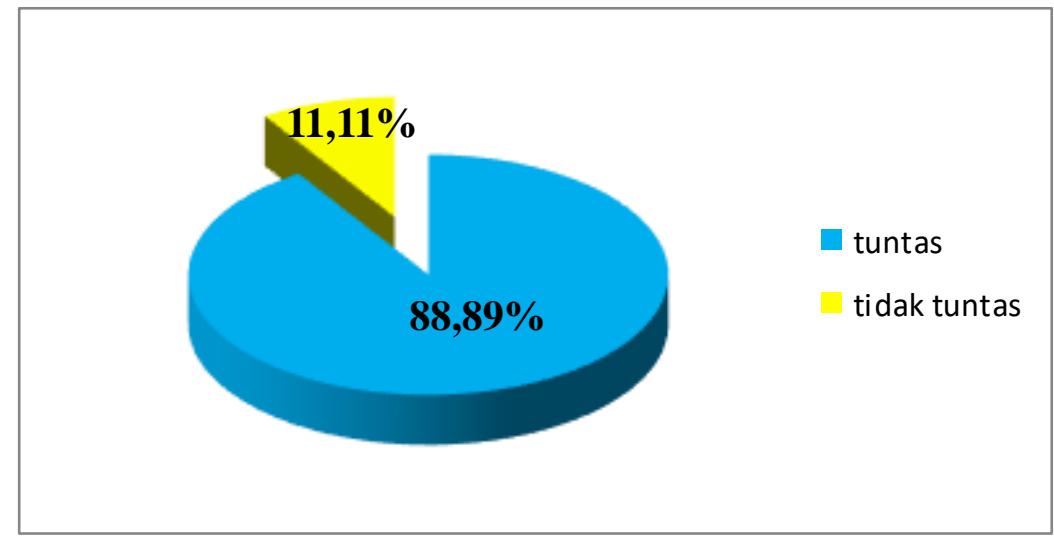

Diagram 4. Ketuntasan belajar siswa secara klasikal siklus II

\section{b. Refleksi}

Refleksi setelah melaksanakan siklus II adalah terdapat peningkatan pada hasil belajar siswa. Hasil belajar pada siklus II yaitu pada tes formatif menunjukkan nilai rata-rata kelas sebesar 84,44 dan persentase ketuntasan belajar mencapai $88,89 \%$. Hal ini dapat menunjukkan adanya peningkatan pada hasil rata-rata kelas yang pada siklus I sebesar 77,78 meningkat pada siklus II menjadi 84,44 . Kemudian pada persentase ketuntasan belajar pada siklus I sebesar $77,78 \%$ meningkat sebesar $11,11 \%$ menjadi $88,89 \%$. Peningkatan tersebut disebabkan karena adanya tindakan-tindakan dari guru dengan melihat refleksi hasil dari siklus I, yaitu guru memperbaiki pembelajarannya dengan mendesain model pembelajaran $\mathrm{PBL}$ agar lebih menarik, misalnya penggunaan media pembelajaran yang bervariasi seperti media audio visual sehingga lebih dapat menarik minat siswa.

\section{c. Revisi}

Dari berbagai data pada siklus I dan perbaikan pada siklus II dalam pembelajaran Matematika di kelas III materi penjumlahan dua bilangan cacah di SDN 02 Banjarsari Pemalang dapat disimpulkan adanya keefektifan dengan penggunaan model pembelajaran PBL berbantuan 
media audio visual yaitu ditunjukkan dengan adanya peningkatan dan sudah tercapainya indikator keberhasilan terhadap hasil belajar siswa.

Pembahasan dalam penelitian ini meliputi dua hal, yaitu pemaknaan temuan penelitian dan implikasi hasil penelitian.

\section{Pemaknaan Temuan Penelitian}

Dari perolehan nilai pretest hasil belajar siswa kelas III tahun ajaran 2020/2021 pada materi penjumlahan dua bilangan cacah, dari 9 siswa yang mendapatkan nilai > $68(\mathrm{KKM})$ hanya 6 siswa $(66,67 \%)$, sementara 3 siswa $(33,33 \%)$ mendapatkan nilai di bawah 68 atau belum mencapai KKM. Bertolak dari kondisi awal tersebut dilakukan penelitian tindakan kelas untuk meningkatkan hasil belajar siswa pada muatan pelajaran Matematika dengan materi Penjumlahan dua bilangan cacah dengan menggunakan model pembelajaran Problem Based Learning (PBL).

Penelitian dilakukan dalam dua siklus. Pada siklus I hasil tes belajar siswa mengalami peningkatan dari sebelumnya, yaitu dengan rata-rata kelas 77,78 dengan ketuntasan belajar secara klasikal sebesar 77,78\%. Meskipun mengalami peningkatan tetapi masih ada 2 siswa yang mendapatkan nilai dibawah KKM yaitu 68.

Siklus II dilaksanakan dengan mempertimbangkan hasil refleksi dari siklus I, yaitu peneliti berusaha memperbaiki kekurangan siklus I ketika siklus II berlangsung, dimana peneliti berusaha memperjelas kembali materi yang diajarkan dengan menggunakan media audio visual.

Usaha-usaha yang dilakukan peneliti untuk memperbaiki penelitian pada siklus II mendapatkan hasil yang cukup baik, terlihat dari tes hasil belajar siswa yang mengalami peningkatan dari rata-rata siswa 77,78 menjadi 84,44 dengan persentase keberhasilan siswa secara klasikal yang tadinya $77,78 \%$ menjadi $88,89 \%$.Peningkatan hasil belajar siswa digambarkan dalam bentuk diagram berikut:

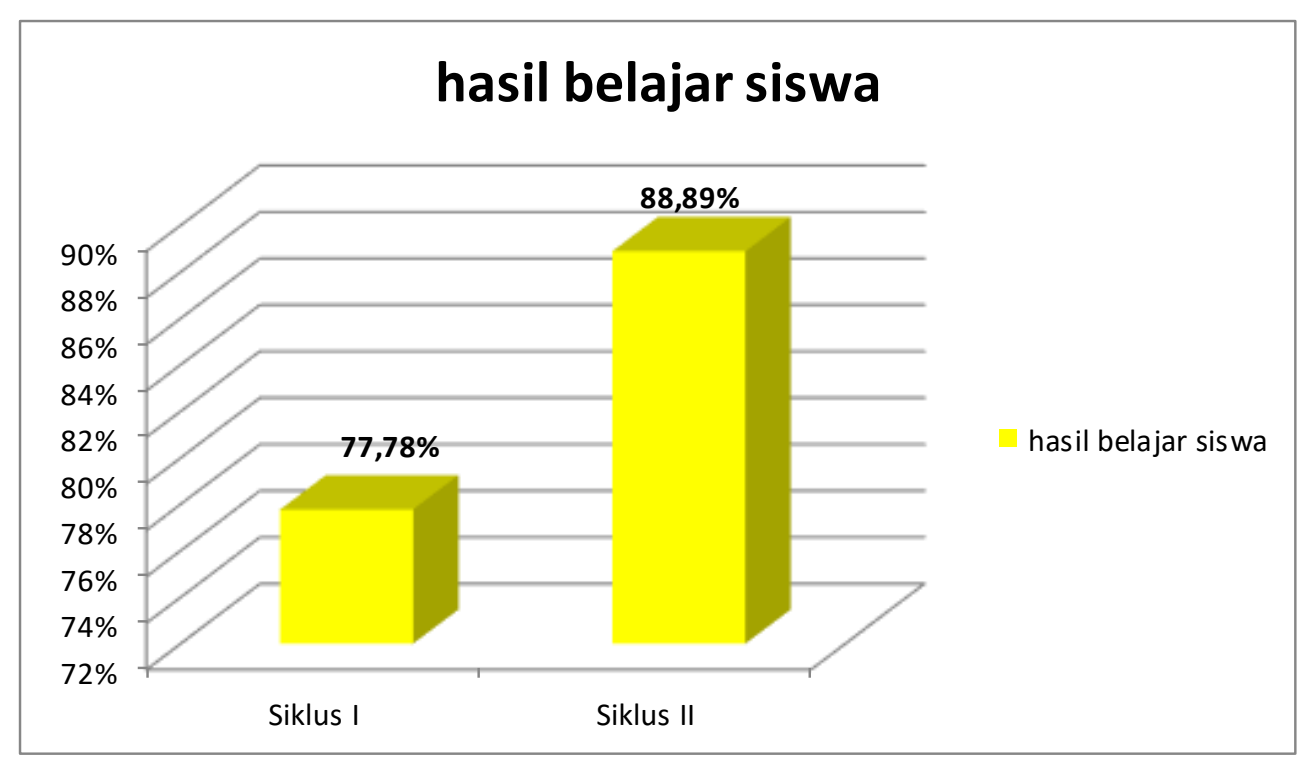

Diagram 5 Peningkatan Hasil Belajar Siswa 


\section{Implikasi Hasil Penelitian}

Berdasarkan temuan dalam penelitian pada pelaksanaan pembelajaran matematika materi penjumlahan dua bilangan cacah di kelas III SDN 02 Banjarsari Pemalang dengan model pembelajaran Problem Based Learning (PBL), maka penggunaan media pembelajaran yang menarik sangat diperlukan. Dalam hal ini, media pembelajaran berperan sebagai sarana untuk menarik minat dan perhatian siswa, sehingga siswa lebih mudah memahami materi pelajaran yang berimplikasi pada meningkatnya hasil belajar. Selanjutnya hasil belajar yang diperoleh dapat direfleksikan dan dianalisis untuk mengetahui kebaikan dan kekurangannya, sehingga pada pembelajaran berikutnya diharapkan akan lebih baik dan lebih berkualitas.

Berdasarkan hasil yang telah dicapai selama pelaksanaan pembelajaran dengan model pembelajaran PBL, siswa mengalami peningkatan baik dari segi motivasi, aspek kognitif, dan aspek afektif. Pada setiap siklus terjadi peningkatan hasil belajar. Oleh karena itu uraian teori yang digunakan mendukung terhadap hasil tindakan kelas yang telah dilaksanakan yaitu aplikasi model pembelajaran PBL berbantuan Media Audio Visual dapat meningkatkan hasil belajar siswa kelas III materi penjumlahan dua bilangan cacah di SDN 02 Banjarsari Pemalang tahun ajaran 2020/2021.

\section{SIMPULAN}

Berdasarkan hasil PTK yang telah dilaksanakan, dapat disimpulkan bahwa penerapan model pembelajaran Problem Based Learning (PBL) dapat meningkatkan hasil belajar matematika siswa pada materi penjumlahan dua bilangan cacah pada kelas III SDN 02 Banjarsari Pemalang tahun ajaran 2020/2021. Hal ini ditunjukkan dengan:

(1) Meningkatnya nilai rata-rata kelas dari 77,78 dengan ketuntasan belajar klasikal $77,78 \%$ pada siklus I menjadi 84,44 dengan ketuntasan belajar klasikal $88,89 \%$ pada siklus II.

(2) Penggunaan Media Audio Visual dapat berperan sebagai sarana untuk menarik minat dan perhatian siswa, sehingga siswa lebih mudah memahami materi pelajaran yang berimplikasi pada meningkatnya hasil belajar pada siklus II.

Maka saran yang dapat diberikan oleh peneliti adalah sebagai berikut :

(1) Pembelajaran dengan menggunakan model Problem Based Learning (PBL) dapat digunakan sebagai pembelajaran alternatif untuk meningkatkan hasil belajar matematika.

(2) Guru hendaknya lebih memotivasi siswa untuk aktif dalam proses pembelajaran matematika sehingga terjalin komunikasi yang lebih baik antar siswa ataupun guru dengan siswa.

(3) Pengarahan kegiatan pembelajaran daring harus disampaikan secara jelas dan sistematis agar siswa paham.

(4) Penggunaan media pembelajaran yang menarik seperti media Audio Visual perlu dilakukan guru agar menarik perhatian siswa, sehingga siswa lebih mudah memahami materi pelajaran yang berimplikasi pada meningkatnya hasil belajar. 


\section{DAFTAR PUSTAKA}

Anni, Catharina Tri, dkk. 2007. Psikologi Belajar. Semarang: Universitas Negeri Semarang Press.

Arikunto, Suharsimi, Suhardjono, dan Supardi. 2008. Penelitian Tindakan Kelas. Jakarta: Bumi Aksara.

Aqib, Zainal, dkk. 2010. Penelitian Tindakan Kelas untuk Guru SD, SLB, dan TK. Bandung: Yrama Widya.

Badan Standar Nasional Pendidikan. 2006. Standar Isi untuk Satuan Pendidikan Dasar dan Menengah. Jakarta: Depdiknas.

Muhsetyo, Gatot, dkk. 2009. Pembelajaran Matematika SD. Jakarta: Universitas Terbuka.

Pitajeng. 2006. Pembelajaran Matematika yang Menyenangkan. Jakarta: Depdiknas.

Riduwan. 2010. Metode dan Teknik Menyusun Tesis. Bandung: Alfabeta

Rifa'i, Achmad dan Catharina Tri Anni. 2009. Psikologi Pendidikan. Semarang: Universitas Negeri Semarang Press.

Sudjana, Nana. 2010. Penilaian Hasil Proses Belajar Mengajar. Bandung: PT Remaja Rosdakarya.

Sugiyono. 2010. Metode Penelitian Administrasi. Bandung: Alfabeta.

Supinah dan Titik Sutanti. 2010. Modul Matematika SD Program Bermutu, Pembelajaran Berbasis Masalah Matematika di SD/MI. Yogyakarta: Kemdiknas.

Trianto. 2011. Mendesain Model Pembelajaran Inovatif Progresif. Jakarta: Kencana 